\title{
STUDENTS' PERCEPTION ON THE ADOPTION OF AN E-TEXTBOOK (DIGITAL) AS AN ALTERNATIVE TO THE PRINTED TEXTBOOK
}

\author{
S. C. Osih* \\ Department of Information Technology \\ e-mail: sharmarosih@gmail.com
}

\section{U. G. Singh*}

Discipline of Information Systems and Technology

e-mail: singhup@ukzan.ac.za

*University of Kwazulu-Natal, Westville campus

Durban, South Africa

\section{ABSTRACT}

The debate between using printed textbooks (traditional) or e-textbooks (digital textbooks) is ongoing in the educational sector. Students are often required to buy textbooks in order to complete a course in the university, and this textbook can either be printed or e-textbook. Students who are usually reluctant to read a printed text or electronic texts are not familiar with the advantages and disadvantages of each text, respectively. Thus, the absence of information prompts the students to employ only one kind of text either digital or printed. The purpose of this research was to investigate whether university students prefer printed textbooks or digital textbooks (e-textbooks). The importance of the research is to understand why students are making the decision to use either traditional textbooks or e-textbooks and what makes them develop these preferences. The benefits that will be derived from this research will help illustrate what the students feel about traditional (printed) and e-textbooks (digital) and the choices that go into making that decision. This article is based on a study that was conducted at a university based in Midrand, South Africa. The study applied the mixed methods to analyse the relationship between perceived ease of use (PEOU), perceived usefulness (PU), attitude (ATT), complexity (CMX) and compatibility (CMP) on Behavioural intention to use. Questionnaire was the main data collection tool from as sample of 80 third year students from the Information Technology department of the university in question. The overall result led to the conclusion that students prefer e-textbook to the printed textbook.

Keywords: printed textbook, e-textbook (digital textbook), perceived usefulness, perceived ease of use, attitude, complexity, compatibility

\section{INTRODUCTION}

Books have been known to be an integral part of the lives of people as they provide a learning foundation from early childhood and grow continuously with people throughout their adult 
lives. A books' purpose is to communicate information of any kind (Byars 2015). Reading maybe regarded as a compound activity when probed closely. It entails more than simply what the vision spots on a sheet. To read means to focus and comprehend the explanation of letters, symbols, words etc. (Byars 2015). At the heart of this digital era, the question arises as to whether the brain responds separately to various text types, more distinctively if the brain responds dissimilarly when symbols, words or letters are introduced to the reader in separate forms. There is a belief that reading from the printed text and reading from the digital text causes the brain to respond differently, thus causing both positive and negative reactions from readers (Byars 2015). Some readers lean more towards using printed text because digital texts are strange to them while the digital age readers are used to reading from tablets, phone and other digital devices thus finding printed text queer (Zhang 2003).

The pervasiveness of the internet is increasing at a very fast rate. The development of Information Technology has without uncertainty created a major influence on the educational sector especially in the tertiary institution (Fang and Schleppegrell 2010)). It has also altered the various learning methods (in the lecture halls) (as well as learning technology) (Zhang 2003). In addition, the Internet has also caused a major transformation in the industry since the development of digital books. According to Shiratuddin and Landoni (2003), the subsequent establishment of mobile electronic readers such as Amazon kindle, IPad and smartphones which provides readers with better reading experience, electronic textbooks (e-textbooks) have been gaining wide interest. The emergence of e-textbooks has created a great opposition to the conventional reading pattern of printed textbooks. Nevertheless, the aim of e-textbooks is not to take the place of printed books but rather to facilitate the reading process making it easier and more convenient (Folb, Wessel and Czechowski 2011). The debate between using printed textbooks or digital textbooks (e-textbooks) is ongoing in the educational sector. This study identifies the textbook preference for the undergraduate student of the university in question.

\section{RESEARCH PROBLEM AND QUESTION}

Students who are usually hesitant towards reading printed text or electronic texts are not familiar with the advantages and disadvantages of each text respectively. Thus, the absence of information prompts the students to employ only one kind of text either digital or printed. Some students feel uncomfortable reading texts electronically as they are not familiar with it and some other students are accustomed to reading text electronically and have totally shunned printed texts. There is a common belief among readers that the success of a reader is based on the specific type of text he or she read or uses (Patton 2014)

The problem is many readers haven't been able to comprehend fully the correlation linking 
the specific types of text (digital and printed) and the success that exists with each of them and thus causing them to make ignorant decision about which text to employ to have the most favourable result academically (Patton 2014). Students are always required to purchase one textbook or the other in order to finish a course and most of these textbooks are accessible in both printed and digital text. Some students find the need to use the printed text as it is easier for them to highlight pages as well as to write side notes within the texts while other students prefer the digital text as it can be more easy-going, and it doesn't demand a great deal of physical strength as in carrying a printed text.

The question on many students' mind is which type of text to use and whether or not it would affect their academic performance in a course. Through this research we will be able to discover the elements affecting the adoption of e-textbooks and Printed textbooks and why university students prefer one to the other.

\section{E-TEXTBOOK DEFINITION}

E-textbooks has been explained in various ways. Researches on e-textbooks describe them as digital texts accessed via electronic screens. The e-textbook concepts started as printed versions of books being converted to electronic versions but, currently e-textbooks are produced as their own original versions in which they have no printed versions of their books (Bennett 2006). Etextbooks through its use of automatic text storage and retrieval process can be referred to as a computerised device with electronic content (Abdullah and Gibb 2008). E-textbooks because of their digital way of accessing reading materials and also being used as a learning tool can be considered an innovation (Maduku 2015).

\section{LITERATURE REVIEW}

Arguments over the use of e-textbook or printed textbook in different work field has been ongoing, however it has become very conspicuous in the educational sector. In the tertiary institution, a textbook is a major tool for learning. The textbook is a major source of information that helps a student further expands on what has been taught in the classroom (RockinsonSzapkiw et al. 2013). The nature of textbooks in this digital age is evolving and 80 per cent of students at the university's own laptops, tablets, and smartphones (Smith and Caruso 2010). The increase in technology has caused the use of electronic device for reading purposes to become popular (Hue, Rosenfeld and Saa 2014). Due to technological advancements, student continuously educate themselves more independently. They have begun utilising new learning strategies which involve electronic devices. With the introduction of e-textbooks, the text structure can be either in a linear or nonlinear form thus creating different ways of learning. E- 
textbooks can be in a nonlinear form, rotating based on the content of the screen as opposed to printed books which are in a linear form with a fixed layout text (Kerr and Symons 2006).

Baier et al. (2011) carried out an investigation into college students' perceptions of designated readings for university course. The research required the data for the students reading habits for their classes as well as their view on reading for a course. Thus, questionnaires were distributed. The outcome showed that an hour or less was spent by the student on the designated reading for the course. Additionally, the study encourages lecturers to find a way to drive and inspire students to complete their assignments by integrating different methods which could include various forms of textbooks. If a text is shown to students in a way that fits their learning style, the students will most likely be inclined to finish their assignment as well as be successful in their reading. Baier et al. (2011) expressed that students find the current resources very appealing and thus the possibility of the odds that the student will read and do the assignment is increased.

Jolliffe and Harl (2008) carried out a research on students' reading at both the secondary school and university levels. A portion of the research included analysing the opinions as well as statements of the students regarding reading for their university course. The following opinions and feelings were expressed by most of the students surveyed: they felt it was unnecessary hence their refusal to read, other students found their textbook to be dull or boring thus making reading difficult and some expressed how time consuming and inconvenient reading can be. This shows that various elements affect whether a student enjoys reading, and also from a certain textbook or not.

Jolliffe and Harl (2008) also discovered that when a text is particularly technology based, the student frequently interacts confidently with the text. The research further discovered that due to its multi-tasking capabilities while reading from a device, students prefer reading via technology. Students appear to flourish in digital situations as well as when making use of etextbooks or any additional form of technology used for reading. These types of text may supply an incentive that would entice students in to reading, motivate them to finish it and assist with their educational achievement. The knowledge is useful for university lecturers, so that they can carry out a more enlightened resolution concerning the textbook kinds they provide to students for a specific subject.

According to Reynolds (2011) e-textbook adoption alongside its wide range of interactive features is envisioned to grow rapidly over the years. For many people, reading books will always be a foundation for learning. Whether it is for personal pleasures or for an educational purpose, the need for books by people will always be continuous. Nevertheless, due to the continuous change in technological advances of the world, different physical forms have been 
taken on by books throughout the past several decades thus, resulting in the division between the printing world and the digital world. E-textbooks and printed textbooks are very different and in order to decide on which to choose from, options need to be weighed ranging from cost to availability and features, as these are all major influences on readers' choices on which type of format they prefer. Understanding student's decision and preferences on both digital textbooks and printed textbooks is very important.

\section{THEORETICAL FRAMEWORK}

Dillon and Morris, (1996) explain user approval as the clear desire in an end-user class to use information technology to support tasks it is intended for. Models and theories have been brought up with the purpose of revealing factors that impact the use of e-textbooks or traditional textbooks. These factors span from an individual's attention on the technology itself to the individual's psychological attributes (Dillon and Morris 1996). Due to the concern as to why a student would decide to make use of either the digital textbook or traditional textbook, it is not possible for a single-variable description to account for the decision made. Hence in order to understand students' preferences, numerous theories have been developed. The decision of the students to use e-textbook or traditional textbooks is a complicated process which involves numerous influencing factors. This research intends to draw from two adoption theories and to evaluate how these theories can help bring meaning and understanding as to why either the etextbook or the traditional textbook is chosen by an individual. Hence, Technology Acceptance Model (TAM) is being adopted for this study and also the Innovation Diffusion Theory (IDT).

\section{TECHNOLOGY ACCEPTANCE MODEL (TAM)}

Technology Acceptance Model (TAM) has a rather dissimilar focal point in opposition to Rogers's Diffusion Model. Its concentration is also on a particular type of innovation and not just the particular type of adoption environment. The TAM focus is on perceived ease of use (PEOU) and usefulness (PU) of the change recognized by the wilful person. Two variables are used to ascertain the probable adoption of the innovation. Research has shown that nearly 50 per cent of the variance in acceptance level can be explained by the TAM models (Davis, Bagozzi and Warshaw 1992). Huang, Lin and Chuang (2007) showed that in terms of establishing adoption, the TAM model worked well.

The fundamental design of TAM has been analysed and enlarged in varieties of IT innovations. Chen and Barnes (2007) discovered that perceived ease of use and perceived usefulness significantly predict Attitude. Chau and $\mathrm{Hu}$ (2001) have shown that an attitude regarding using a technology significantly determines Behavioural intention. 
Perceived usefulness (PU) can be explained as the magnitude to which an individual assumes utilisation of a certain method to increase their performances in their jobs (Davis 1989). In addition, perceived usefulness is a function of perceived ease of use.

Perceived ease of use (PEOU) can be explained as an extent to which an individual assumes utilisation of a certain method that requires no efforts (Davis 1989).

Attitude is ones (good or bad) feeling either about executing the target behaviour (Davis 1989). The validity of TAM from research works above has led to the upcoming hypothesis:

- H1: Perceived usefulness impacts Behavioural intent to use e-textbooks

- H1a: Perceived usefulness impacts attitude to use e-textbooks

- $\quad \mathrm{H} 2$ : Perceived ease of use affects Behavioural intent to use e-textbooks

- H2a: Perceived ease of use affects Perceived usefulness to use e-textbooks

- $\quad$ H2c: Perceived ease of use affects attitude to use e-textbooks

\section{DIFFUSION OF INNOVATION THEORY}

Innovation diffusion theory by Rogers (1995) speculates that recognized attributes of a change influences the adoption behaviour of a user. Compatibility and Complexity are the perceived characteristics. Rogers (1995) states that 49-87 per cent of the variation of innovations adoption can be demonstrated by these variables.

Compatibility can be explained as the extent to which an innovation can be seen as constant with the continuous merits, wants, and potential of adopters past experiences (Moore and Benbasat 1991).

Complexity can be explained as an extent to which an innovation is being seen as difficult to comprehend (Rogers 1995)

The validity of innovation diffusion theory from the research works above has led to the following hypothesis:

- H4: Compatibility impacts Behavioural intent to use e-textbooks

- H4a: Compatibility impacts perceived usefulness to use e-textbooks

- H5: Complexity impacts Behavioural intent to use e-textbooks

- H5a: Complexity impacts attitude to use e-textbooks 


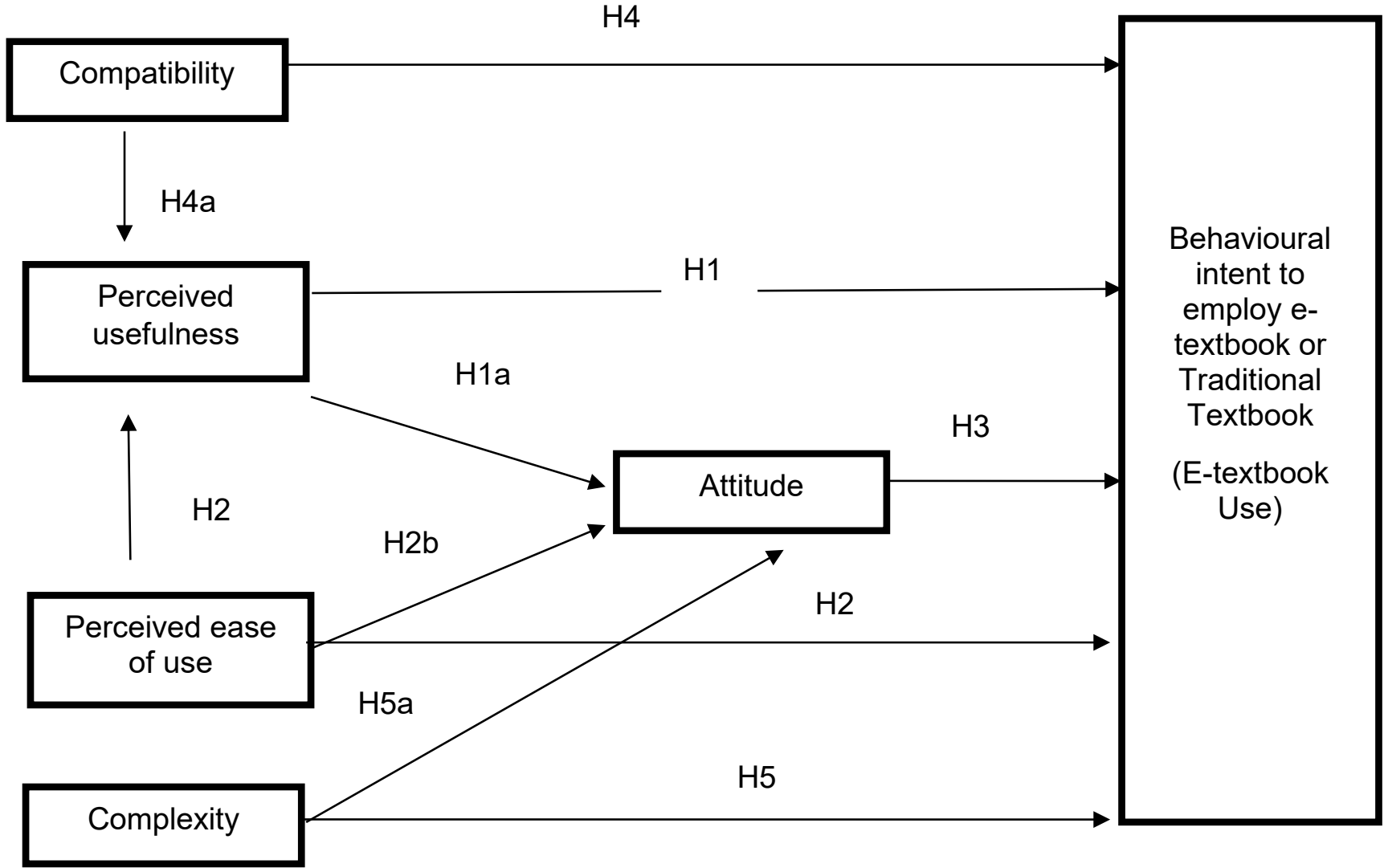

Figure 1: Conceptual framework

\section{RESEARCH METHODOLOGY}

Welman, Kruger and Mitchell (2005) explained research methodology as a framework of research which details the methods and strategies to be utilised for data gathering. Krauss (2005) considered research methodology as a framework for gathering, measuring, and examining of data in order to accomplish the purpose of a research. Hair et al. (2008) observed that the quality of gathered data portrays the strength of the methodology utilised to assemble them. An acceptable method used to gather data makes certain that the reliability and validity of the research will not be jeopardised.

\section{RESEARCH DESIGN}

Research design can be explained as a design that is used to collect, assess and investigate the data which is set up on the essence of research investigation (Sekaran and Bougie 2016). Research design is the "blue print" to give advice and perception into the study's investigation purpose. It involves documentation of statistics, basis for the choice of these documentations, how the information will be gathered, entry and moral matters, and examining of statistics gathered (Bryman and Bell 2011). The study adopted the mixed method. 


\section{SAMPLE AND SAMPLE SIZE}

Sample is explained as a small section of the population with similar features as those in the entire population. Welman et al. (2005) stated that a representative sample makes reference to a small image or small class of a particular population. Bryman and Bell proposed than in every research business, a sample is obtained from the overall population as a representative of that population. Cant et al. (2005) stated that sample size can be defined as the entire number of components incorporated in the research. It means the number of respondents which should be incorporated in the research and this is deemed very crucial for any study because the sample size drawn has an influence on standard and generalization of data (Cant et al. 2005). Sample size decreases the likely mistake of generalizing a population. Thus, a sample size chosen and utilised in a research should be big enough to make certain that an authentic and reasonable conclusion can be drawn about the population (Lacobacci and Churchill 2010). The sample size used here will be the $3^{\text {rd }}$ year students of the Department of Information Technology of that particular university which is a total of 80 students.

\section{THE RESEARCH INSTRUMENT}

Questionnaires are seen as crucial instruments to gather suitable data from respondents. Kumar (2019) explained questionnaires as a written item of questions, response or statement to which the respondents answer. Questionnaires are survey approach that make use of systemised set of questions, which permit respondents' response to be methodically compared or contrasted. Questionnaires must be designed meticulously in order to guarantee transparency. The questionnaire questions may be tailored to calculate various responses. For instance, (true/false) and interval replies (i.e. Likert scale) or semantic varying answers ("sometimes" or "always"). In questionnaires, respondents are required to read the questions, translate what is required, and then write down the answers (Trochim 2000). For this research, the self-administered questionnaire was utilised as the data gathering instrument

In this study, the researcher chose a structured questionnaire. Structured questionnaires comprise of open and closed ended questions. The closed ended questions supply a set of prearranged responses from which the respondents have to select applicable response. While some of the questions require one to explore their textbook types, most of the questions are chosen to get suitable information regarding the student's perception on e-textbooks adoption and the influencing factors as such. In this study, survey questionnaire was utilised to gather data because of its various merits and its capability to produce the most adequate range of authentic data. 


\section{DATA ANALYSIS}

According to Osuala (1982), analysis is defined as the ordering and breaking down of data into constituent parts. First a preliminary assessment of the data is conducted, then the data is cleaned and transformed, and the descriptive statistics are presented. The hypothesises are now tested and analysed.

\section{RELIABILITY SCALES}

The reliability of the Perceived Usefulness (PU), Perceived ease of use (PEOU), Attitude (ATT), Compatibility (CMX), Complexity (CMP) and e-textbook use (USE) scales was tested using the Cronbach's alpha coefficient (Fields, 2013). The analysis shows that five scales overall were above 0.90 which shows that the scale is not only reliable but excellent as the overall alpha coefficient result, $\mathrm{PU}$ is 0.986 , PEOU is 0.977 , ATT is $0.978, \mathrm{CMX}$ is 0.952 and CMP is 0.965 and the sixth scale was above 0.70 , USE is 0.780 which shows that it is not only reliable but also acceptable. All in all, each scale was proven to be reliable

\section{FINDINGS}

Perception of e-textbook and printed textbook vary with students. The reason for this research was to determine whether the undergraduate students of the university in question, prefer etextbook or printed textbook. The research question for this study: What is the textbook preference of the undergraduate students of this university?

\section{DISCUSSION PERTAINING TO HYPOTHESIS 1}

Hyphotesis1: Perceived Usefulness impacts Behavioural intent to use e-textbooks and Hypothesis 1a: Perceived Usefulness impacts attitude to use e-textbooks

The hypothesis that perceived usefulness impacts student's behaviour to use e-textbook and perceived usefulness impacts student's attitude to use e-textbook is supported in this study. The correlation analysis showed that there was 83.722 per cent shared magnitude between PU (Perceived Usefulness) and Behavioural intention to use e-textbooks which shows the existence of a strong positive and significant relationship between them and the Regression analysis also confirmed that perceived usefulness has a positive influence on intention to use e-textbooks $\left(\mathrm{R}^{2}=.838\right)$. This means that Perceive Usefulness is 83.8 per cent responsible for the student's perception of utilising a digital textbook while the correlation analysis showed that there was 75.342 per cent shared magnitude between PU (Perceived usefulness) and AT (Attitude) which also shows the presence of a strong and significant relationship between PU and AT. The 
regression analysis on that also showed that perceived usefulness has a positive influence on the student's attitude to use e-textbooks $\left(\mathrm{R}^{2}=.754\right)$, meaning that perceived usefulness is 75.4 per cent responsible for the student's attitude towards using e-textbooks.

The result of this hypothesis is in line with the study of Hue et al. (2014) who stated that the increase in technology has caused the use of electronic devices for reading to become popular and also the study of Kerrs and Symons (2006) who stated that due to technological advancement, students continuously educate themselves more independently, and they have begun utilising new learning strategies which involve electronic devices.

\section{DISCUSSION PERTAINING TO HYPOTHESIS 2}

Hypothesis 2: Perceived Ease of Use affects Behavioural intent to use e-textbooks.

Hypothesis 2a: Perceived Ease of Use affects Perceived usefulness to use e-textbooks.

Hypothesis 2b: Perceived Ease of Use affects attitude to use e-textbooks.

The hypothesis that Perceived ease of use influences the students' Behavioural intent to use, perceived ease of use affects Perceived usefulness to use e-textbooks and that Perceived Ease of Use affects students' attitude to use e-textbooks is supported in this study. The correlation analysis showed that that there was 66.585 per cent shared magnitude between PEOU and Behavioural intention to use e-textbook which shows a strong and significant relationship between them. The regression analysis showed that that Perceived ease of use has a positive influence on Behavioural intention to use e-textbook $\left(\mathrm{R}^{2}=.665\right)$ which means Perceived Ease of Use plays at least 66.5 per cent role in a student's intention to utilise etextbooks. The correlation analysis showed that there was 66.558 per cent shared magnitude between PU and PEOU which shows a strong and significant relationship between them. The regression analysis showed that Perceived Ease of Use has a positive influence on Perceived Usefulness to use e-textbooks $\left(\mathrm{R}^{2}=.686\right)$ meaning Perceived Ease of Use has a 68.6 per cent influence on a student's perceived usefulness to use e-textbooks. The correlation analysis showed that there was 74.649 per cent shared magnitude between PEOU and AT which shows a strong and significant relationship between them. The regression analysis indicated that Perceived ease of use of e-textbooks has a positive effect on attitude to the use of e-textbooks. $\left(\mathrm{R}^{2}=.747\right)$ meaning Perceived Ease of Use has 74.7 per cent influence on a student attitude to use e-textbooks.

The result of this hypothesis is in line with the study by Baier et al. (2011) which stated that if a text is shown to a student in a way that fits his learning style, the student will most likely be inclined to finish his assignment as well as be successful in his reading. 


\section{DISCUSSION PERTAINING TO HYPOTHESIS 3}

Hypothesis 3: Attitude affects Behavioural intent to use e-textbooks.

The hypothesis that attitude affects behavioural intent to use e-textbooks is supported in this study. The correlation analysis showed that there was 66.422 per cent shared magnitude between AT and Behavioural intention to use e-textbooks indicating a strong and significant relationship between them. The regression analysis indicated that Attitude to use of e-textbooks has a positive effect on behavioural intent to the use e-textbooks $\left(\mathrm{R}^{2}=.664\right)$ meaning attitude has a 66.4 per cent influence on a student's intention to use e-textbooks. The result of this hypothesis is in line with the study: Jolliffe and Harl (2008) also discovered that when a text is particularly technology based, the student frequently interacts confidently with the text.

\section{DISCUSSION PERTAINING TO HYPOTHESIS 4}

Hypothesis 4: Compatibility impacts Behavioural intent to use e-textbooks

Hypothesis 4a: Compatibility impacts Perceived Usefulness to use e-textbooks

The hypothesis that compatibility impacts behavioural intent to use e-textbooks and compatibility impacts perceived usefulness to use e-textbooks is supported in this study. The correlation analysis showed that that there was 41.216 per cent shared magnitude between CMP and Behavioural intention to use e-textbooks indicating a strong and significant relationship between them. The regression analysis showed that Compatibility has a positive effect on Behavioural intent to use e-textbooks $\left(\mathrm{R}^{2}=.412\right)$ meaning compatibility has 41.2 per cent influence on a student's intent to use e-textbooks. The correlation analysis showed that there was 46.512 per cent shared magnitude between CMP and PU indicating a strong and significant relationship between them. The correlation analysis showed that compatibility has a positive effect on Perceived Usefulness of e-textbooks $\left(\mathrm{R}^{2}=.466\right)$ meaning compatibility has 46.6 per cent influence on a student's intent to use e-textbooks

The result of this hypothesis is in line with the study by Jolliffe and Harl (2008) which discovered that due to its multi-tasking capabilities while reading from a device, students prefer reading via technology. Students appear to flourish in digital situations as well as when making use of e-textbooks or any additional form of technology used for reading. The study by Jones and Brown (2011) stated that the students favour the digital textbook more because of its unique attributes such as its capability to find definitions, word articulation, automated page turning and the read aloud option

\section{DISCUSSION PERTAINING TO HYPOTHESIS 5}

Hypothesis 5: Complexity impacts Behavioural intent to use e-textbooks 
Hhypothesis5a: Complexity impacts attitude to use e-textbooks

The hypothesis that complexity impacts Behavioural intent to use e-textbook and complexity impacts attitude to use e-textbooks is not fully supported in this study. The correlation analysis showed that there was 1.144 per cent shared magnitude between CMX and $\mathrm{U}$ meaning there is a positive (weak) but non-significant relationship. The regression analysis showed that Complexity has a weak positive effect on behavioural intent to use e-textbooks $\left(\mathrm{R}^{2}=.011\right)$ meaning complexity has a 1.1 per cent influence on a student's intent to use etextbook. The correlation analysis showed that there was 2.822 per cent shared magnitude between CMX and AT indicating a positive but non-significant relationship. The regression analysis showed that complexity has a positive effect on attitude to use of e-textbooks. $\left(\mathrm{R}^{2}=.028\right)$ meaning complexity has 2.8 per cent influence on a student attitude to use etextbooks.

The result above shows that complexity though positive has little or no influence on students use of e-textbook making it almost insignificant and this can be seen also in the answers of the responders of the on the complexity statements in part b of the questionnaire. Over 50 per cent of them disagreed that complexity influences the attitude as well as their intention to use.

\section{WHAT IS THE TEXTBOOK PREFERENCE OF THE UNDERGRADUATE STUDENTS OF THIS UNIVERSITY?}

The outcome of the data collected shows that the undergraduate students of that specific university prefer e-textbooks to printed textbooks. This is based on the analysis of three questions. The questions asked students which textbook they prefer, and they were given the choice of either e-textbooks or printed and their reason for choosing the specific textbook as well as which textbook they use for most of their courses. The questions were used to help understand the student's textbook preference.

Overall, most of the students preferred e-textbooks to printed textbooks. 61.3 per cent said they preferred e-textbook while the rest 38.8 per cent preferred printed textbooks. Their reason for choosing the specific textbook were: 20 per cent said price, 30 per cent said convenience, 8.8 per cent said portable and easy access, 6.3 per cent said easy to read and highlight, and the last 35 per cent said textual features. The textual feature being the most selected is in line with Kerr and Symons (2006) which showed that with the introduction of etextbooks, the text structure can either be linear or non-linear changing based on the content of the screen as opposed to printed textbooks which are in linear form with fixed layout text. Also, as for which textbook they use for most of their course, 66.3 per cent selected e-textbooks while 
the rest 33.8 per cent chose printed textbooks. The significant difference in these percentages results in the conclusion that students are more comfortable using e-textbooks over printed textbooks, hence the e-textbook preference.

The overall results show that the undergraduate students of that specific university prefer e-textbooks over printed textbooks. Durwin and Sherman (2008) said students are well informed of the textbook attributes that are favourable to their learning, thus making them better judges of which textbook to use.

\section{CONCLUSION}

Various conclusions were deduced established on the data collected and results analysed regarding students' "perceptions" of the adoption of e-textbooks as an alternative to printed textbooks. The results of the data collected shows that most of the students $(61.2 \%)$ prefer the e-textbooks as opposed to (38.8\%) for the printed textbooks. Jolliffe and Harl (2008) carried out a research that drew a conclusion which support this research. The study showed that when a text is particularly technology based, the student frequently interacts confidently with the text. The research further posited that due to its multi-tasking capabilities while reading from a device, students prefer reading via technology. The digital text (e-textbooks) made available by the university for their study was used by majority $(78.8 \%)$ of the students as they were aware of it as opposed to the 21.2 per cent who claimed they were unaware of the e-textbooks. Furthermore, most of the respondents said that they had been using the e-textbook on their tablet for more than a year $(53.8 \%)$. while 26.2 per cent reported they had been using etextbooks provided for about a year while 20.0 per cent had been using them for less than a year. In analysing the information, most students attested that they study more profitably and more frequently using e-textbooks and preferred using e-textbooks as opposed to printed textbooks. In addition, most of the respondents (about 67.5\%) did not find reading with etextbook on tablets difficult compared to the printed textbooks.

The results also showed that majority of the students were motivated to use their etextbooks on their tablet due to their academic recommendations $(30.0 \%)$ or easy access $(28.8 \%)$, convenience and portability $(16.2 \%)$ as well as ease of use $(16.2 \%)$. In this research, e-textbook was reported by majority of the respondents (about $61.2 \%$ ) to be used for most of their studies. Falc (2013) carried out a research which brought about the conclusion that students revealed the desire to choose which textbook to use. In the study, she discovered that even though many of the students were utilising the same textbook version, they also exhibited gratitude for the capability to select whichever textbook works best for them.

All of the students who utilised the textbook type described in this research and the 
student's perception and opinion of the textbooks, supports the conclusion that the undergraduate students prefer to utilise e-textbooks rather than printed textbooks.

\section{REFERENCES}

Abdullah, Noorhidawati and Forbes Gibb. 2008. Students' attitudes towards e-books in a Scottish higher education institute: Part 1. Library review 57(8): 593-605.

Baier, Kylie, Cindy Hendricks, K. Warren Gorden, James E. Hendricks and Lessie Cochran. 2011. College students' textbook reading, or not. American Reading Forum Annual Yearbook Vol. 31: $1-8$.

Bennett, Linda. 2006. E-books: The options: A manual for publishers. Publishers Association.

Bryman, A. and E. Bell. 2011. Ethics in business research. Business Research Methods 7(5): 23-56.

Byars, M. N. 2015. Printed books versus digital books. California Polytechnic State University.

Cant, M., C. Gerber-Nel, D. Nel, and T. Kotze. 2005. "Marketing Research. Claremont: An Examination of the Substitutability of Founders' Human and Financial Capital in Emerging Business Ventures. Journal of Business Venturing 13(2005): 353-369.

Chau, Patrick Y. K. and Paul Jen-Hwa Hu. Information technology acceptance by individual professionals: A model comparison approach. Decision Sciences 32(4): 699-719.

Chen, Yu-Hui and Stuart Barnes. 2007. Initial trust and online buyer behaviour. Industrial Management \& Data Systems 107(1): 21-36.

Davis, F. D. 1989. Perceived usefulness, perceived ease of use, and user acceptance of information technology. MIS Quarterly: 319-340.

Davis, Fred D., Richard P. Bagozzi and Paul R. Warshaw. 1992. Extrinsic and intrinsic motivation to use computers in the workplace 1. Journal of Applied Social Psychology 22(14): 1111-1132.

Dillon, Andrew and Michael G. Morris. 1996. User acceptance of new information technology: Theories and models. Medford, NJ: Information Today.

Durwin, Cheryl Cisero and William M. Sherman. 2008. Does choice of college textbook make a difference in students' comprehension? College Teaching 56(1): 28-34.

Falc, Emilie O. 2013. An assessment of college students' attitudes towards using an online e-textbook. Interdisciplinary Journal of E-Learning and Learning Objects 9(1): 1-12.

Fang, Z. and M. J. Schleppegrell. 2010. Disciplinary literacies across content areas: Supporting secondary reading through functional language analysis. Journal of Adolescent \& Adult Literacy 53(7): 587-597.

Folb, Barbara L., Charles B. Wessel and Leslie J. Czechowski. 2011. Clinical and academic use of electronic and print books: The Health Sciences Library System e-book study at the University of Pittsburgh. Journal of the Medical Library Association: JMLA 99(3): 218.

Hair, Joseph F., Mary Celsi, David J. Ortinau and Robert P. Bush. 2008. Essentials of marketing research. New York, NY: McGraw-Hill/Higher Education.

Huang, Jen-Hung, Yu-Ru Lin and Shu-Ting Chuang. 2007. Elucidating user behavior of mobile learning: A perspective of the extended technology acceptance model. The Electronic Library 25(5): 585-598.

Hue, Jennifer E., Mark Rosenfield and Gianinna Saá. 2014. Reading from electronic devices versus hardcopy text. Work 47(3): 303-307.

Jolliffe, David A. and Allison Harl. 2008. Studying the reading transition from high school to college: What are our students reading and why? College English 70(6): 599-617.

Kerr, Matthew A. and Sonya E. Symons. 2006. Computerized presentation of text: Effects on children's reading of informational material. Reading and writing 19(1): 1-19.

Kumar, Ranjit. 2019. Research methodology: A step-by-step guide for beginners. Sage Publications 
Limited.

Lacobacci, D. and G. A. Churchill. 2010. Marketing research. Methodological foundations. $10^{\text {th }}$ edition. Mason, $\mathrm{OH}$ : South-Western Cengage Learning.

Maduku, Daniel K. 2015. An empirical investigation of students' behavioural intention to use e-books. Management Dynamics: Journal of the Southern African Institute for Management Scientists 24(3): 3-20.

Moore, Gary C. and Izak Benbasat. 1991. Development of an instrument to measure the perceptions of adopting an information technology innovation. Information Systems Research 2(3): 192-222.

Osuala, Esogwa C. 1982. Introduction to research methodology. Africana-FEP Publishers.

Patton, Kelly A. 2014. Digital vs. in-print textbooks: Relationships and trends for college students. PhD dissertation. Bowling Green State University.

Reynolds, Rob. 2011. Trends influencing the growth of digital textbooks in US higher education. Publishing Research Quarterly 27(2): 178-187.

Rockinson-Szapkiw, Amanda J., Jennifer Courduff, Kimberly Carter and David Bennett. 2013. Electronic versus traditional print textbooks: A comparison study on the influence of university students' learning. Computers \& Education 63: 259-266.

Rogers, Everett M. 1995. Lessons for guidelines from the diffusion of innovations. Joint Commission Journal on Quality and Patient Safety 21(7): 324-328.

Sekaran, U. and R. Bougie. 2016. Research methods for business: A skill building approach. John Wiley \& Sons.

Shiratuddin, Norshuhada and Monica Landoni. 2003. E-book technology: Devices, books, and book builder. Information Technology in Education Annual 2003 1(2003): 105-138.

Smith, Shannon D. and Judith Borreson Caruso. 2010. The ECAR Study of Undergraduate Students and Information Technology. Key Findings. EDUCAUSE (2010).

Trochim, W. M. 2000. The research methods knowledge base. http://www.socialresearchmethods. net $/ \mathrm{kb}$ (Accessed 13 November 2018).

Welman, C., F. Kruger and B. Mitchell. 2005. Research methodology. What is environmental education. Cape Town: Oxford University Press.

Zhang, Dongsong. 2003. Powering e-learning in the new millennium: An overview of e-learning and enabling technology. Information Systems Frontiers 5(2): 207-218. 